\title{
Strategic Planning Systems and Firm Performance in the Export Processing Zones
}

\author{
Juliana Mulaa Namada ${ }^{*}$, Vincent Bagire ${ }^{2}$, Evans Aosa ${ }^{3}$, Zachary B. Awino ${ }^{3}$ \\ ${ }^{1}$ Chandaria School of Business, United States International University-Africa, Nairobi, Kenya \\ ${ }^{2}$ Makerere University Business School, Kampala, Uganda \\ ${ }^{3}$ School of Business, University of Nairobi, Nairobi, Kenya \\ Email: ^jnamada@usiu.ac.ke
}

How to cite this paper: Namada, J.M., Bagire, V., Aosa, E. and Awino, Z.B. (2017) Strategic Planning Systems and Firm Performance in the Export Processing Zones. American Journal of Industrial and Business Management, 7, 487-500.

https://doi.org/10.4236/ajibm.2017.74035

Received: January 24, 2017

Accepted: April 27, 2017

Published: April 30, 2017

Copyright (c) 2017 by authors and Scientific Research Publishing Inc. This work is licensed under the Creative Commons Attribution International License (CC BY 4.0).

http://creativecommons.org/licenses/by/4.0/

\begin{abstract}
This study focused on strategic planning systems as predictors of performance in a developing country context. These concepts have not been adequately investigated in extant strategy literature. We contended that strategic planning systems should be emphasized as a configuration and not by its domains. The influence of resources, management participation and planning techniques on performance showed positive and significant results. In support of our conceptualization, the results were that strategic planning systems as an aggregate factor has a stronger influence on performance than its domains. We conclude that the configuration of planning systems with its theoretical underpinning in the dynamic capabilities and resource based view, explains performance variations among firms.
\end{abstract}

\section{Keywords}

Strategic Planning Systems, Performance, Resources, Management

Participation, Planning Techniques, EPZ, Kenya

\section{Introduction}

Strategic planning and performance implications are key areas of investigation in strategic management research. Scholars advocate for strategic planning as a basis of better performance. [1] argued that strategic planning enables firms to achieve an alignment with the environment. They posit that strategic planning channels attention and behavior to specific plans thereby driving out important innovations and creativity [2]. Hence, the debate on the relationship between strategic planning and firm performance is inconclusive [3] [4]. Empirical research has sought to elucidate the relationship but the results are fragmented, contradictory and no consensus has yet emerged [5] [6]. The answer to the on- 
going debate could lie in an investigation of strategic planning systems configuration. There are still scanty empirical tests of these phenomena in Export Processing Zones across Africa particularly in Kenya. Conceptually, Export Processing Zones (EPZs) refer to geographically/juridical bound areas where different levels of trade are permitted to produce goods for export [7]. EPZ firms are given special incentives in form of tax exemptions, duty free imports and exports, exemptions from labor regulations and in turn superior performance expected, [8] [9]. However, EPZs have generated mix performances and several major pitfalls have often precluded their full effectiveness and improved performance. This paper therefore presents a study on strategic planning systems in the Kenyan EPZ. The paper begins with a general background narrowing down to the knowledge gap, gives a theoretical overview, methods used, results and discussion, implications, conclusion and limitations.

\section{Conceptual Analysis}

Strategic planning systems are multifaceted management systems that are contextually embedded in organizations, [10]. They are structured entities that organize and coordinate the activities of the managers who do the planning. An effective strategic planning system takes into account specific firm situations along the dimensions of time and diversity. While extending this line of argument, [11] defined strategic planning systems as complete sets of processes and entities through which a firm does planning. In this study strategic planning system is conceptualized in terms of planning resources, management participation and planning techniques. Therefore, strategic planning systems consist of the people who do the planning as well as the mechanisms of planning. In this study we considered resources, management participation and planning tools as predictors of performance. The strategic planning systems play a significant role towards the achievement of long term objectives against specific inputs.

Strategic planning systems are among the least evaluated functions in organizations. Empirical research has been directed to the planning processes which focus on the steps in strategic planning rather than systems [5] [12]. However, focusing on planning processes does not provide results that are operationally useful to management, [11]. To fairly asses strategic planning, attention need be focused on the degree to which diverse benefits are achieved and the specific systems that facilitate achievement of various benefits. [13] argued that strategic planning evaluation needs a methodological framework involving the assessment of the system inputs, outputs, feedback mechanisms and the relative impacts made in terms of goal achievement.

Performance is an action directed towards certain level of results. [14] defined performance as the ability of an object to produce results in a dimension determined in relation to a target. It is the ultimate test of strategic choices made by firms. Performance is linked to actions emanating from certain sets of decisions and actions. [15] posited that performance is a multidimensional construct. $\mathrm{He}$ observed that any single index may not provide a comprehensive understanding 
of the performance relationship relative to the constructs of interest. Therefore, it is important to look at multiple indicators. Performance is a construct with multiple indicators [16]. Financial measures were popular for many years but have been criticized for limitations based on the scope of accounting manipulations, undervaluation of assets and distortions due to depreciation policies [14]. Further, [17] emphasized on the comprehensive performance measurement systems comprising of both financial and non financial measures through the balanced score card. This study used both financial and non financial measures of organizational performance. In the following section we present related literature in which we underpin the theoretical anchorage of resources, management participation, planning tools and performance.

Different theories have attempted to explain strategic planning in organizations. Literature portrays better performance as a function of strategic planning undertaken by firms. Strategic planning recognizes the need for organizations to establish a formal link with the external environment. Environment is a source of information, opportunities as well as scarce resources sought after by organizations, [18]. Therefore, strategic planning is as a result of both deliberate learning and emergent learning. This study draws from the resource based view [19] and dynamic capabilities theory [20]. The debate on the application of these theories in different organizational contexts has provided new conceptual insights in extant literature [21]. For example [22] has elaborated on the environmental contingences in enterprise performance and theoretical foundations in the ordinary and dynamic capabilities of the firm.

The growth of a firm internally and externally depends on the manner in which its resources are employed. Building on the inroads made by [19] [23] argued that for the firm, resources and products are two sides of the same coin. In other words, while the firm's profits are directly driven by products, they are indirectly driven by resources which are used for production. Firms may earn super profits by indentifying and acquiring resources which are critical to the development of the demanded products. Therefore, the critical task of top management is to develop new and valuable products through the exploitation of core competencies.

Dynamic capabilities theory focuses on how firms change valuable resources over time through a value creating process [20]. Working paper was the first contribution to dynamic capabilities theory. They defined dynamic capabilities as the firm's ability to integrate, build and configure internal and external competencies to address rapidly changing environment. Through dynamic capabilities, firms avoid developing core rigidities, which inhibit development, generate inertia and stifle innovation [24].

Dynamic capability theory explains why many once successful firms struggle to survive or fail completely as the environment changes due to the inability to adapt successfully. [22] argued that it is not only the resources that matter but also the mechanisms by which firms learn and accumulate new skills. Dynamic capability is about the capacity of an organization to purposefully create, extend 
and modify its resource base [25].

\subsection{Resources and Performance}

Resource based view considers firms as sets of resources that produce competitive advantage. This theory is rooted in the work of [23] who considered firms as bundles of resources [19]. Defined resources as those assets which are tied semi permanently to a firm. They are the assets a firm owns and are externally available and transferable. They include brand names, trade contacts, technology knowledge, efficient procedures and capital. Firms which become resource holders maintain relative positions vis-a-vis other holders as long as they act rationally. Borrowing from [26] five forces, [19] contended that entry barriers are resources since they contain mechanisms which make resource holder defensible. Economies of scale are a prime example of a resource which is an entry barrier.

Resource based view is useful in understanding the growth of the firm. However, it lacks substantial managerial implications. It emphasizes managerial development of the resources but is silent on how it should be done [27]. Further it makes the illusion of total control, trivializing property rights while exagge-rating the extent to which managers control resources and predict future value [28]. According to [27] resource based view is relevant to large firms with significant market power. He contended that small firms can not base survival on their static resources thereby falling beyond the bounds of resource based view. Further, resource based view is more relevant to firms striving for sustained competitive advantage, for firms satisfied with their competitive position resource based view is irrelevant. By nature and scope resource based view focuses on the resources while ignoring process which transform the resources into customer value.

We therefore propose that:

Hypothesis 1: Resources have a significant influence on performance.

\subsection{Management Participation and Performance}

[29] observed that management participation generate informational, affective and emotional effects. It means that participation enforces positive organizational effectiveness specifically in terms of information sharing and development of commitment amongst all the actors. Participation by management also facilitates commitment to the plan thereby reducing behavioral impediments that may lead to strategy implementation failure.

Participation focuses on involvement in processes at different levels. Participation taps into concepts of breath and depth of involvement [30]. Defined management participation as the collective level of management involvement within and across the firm. Management spreads beyond the top executive to include middle and lower cadre managers. Literature suggests that participative management approach could increase the firms informational processing, utilize knowledge dispersed across the firm, provide more alternatives, facilitate op- 
portunity recognition and help the organization to avoid overlooking good ideas ([30] [31]).

[32] Identified three possible types of middle level management involvement in strategic planning. They argued that managers synthesize, interpret and channel information to the executive management. [33] further identified the fourth type of management involvement stemming from the middle level as implementing deliberate strategy through action planning. [33] argued that a certain degree of uniformity is required among middle level managers for an organization to achieve consistency. He observed that such consistency is associated with improved performance. Conversely, [34] found that involvement of middle level management increases an understanding of the resulting goals, leading to convergence of strategic priorities.

Hence we propose that:

Hypothesis H2: Management participation has a significant influence on performance.

\subsection{Planning Tools and Performance}

In line with this argument, [35] established techniques such as benchmarking and establishing key success factors in an industry over time leads to effectiveness of the planning system. Similarly, a study conducted by [36] revealed that strategic planning systems are associated with superior performance in all industrial settings. He argued that strategic planning systems are developed to integrate functional activities in marketing, production, human resource function together with research and development. Long term organizational actions like participation at different levels and application of appropriate techniques facilitate corporate performance.

[37] have posited that the maturity of any academic discipline is judged by the extent to which its theories and techniques are employed in practice. Therefore, strategic planning techniques as models used in analysis of business environment are anchored in theory. They are used in translating strategy into business results. When strategic planning suffered a downturn in popularity and influence in the 1970s, largely it was due to the inability of the strategic planning techniques to deliver what was expected [12]. [38] argued that using strategic planning techniques enhances a manager's analytical skills. An effective planning approach seeks to learn by examining the past [38] and links the future through planning techniques [39]. Navigating turbulent environment requires a strategic compass which relies on the use of analytical tools.

Strategic planning techniques enable firms to think strategically. They are possible means of fostering creativity and analytical mindset within organizations. In the competitive positioning paradigm, [25] centers his argument on the premise that firms position themselves within the competitive business environment through the use of a variety of strategic techniques aimed at generating superior performance. [38] argued that planning techniques could integrate strategic planning into the core management process. Similarly, [40] noted that 
planning techniques enable managers to transform data into valuable decisions and suitable actions. To this end, [41] posited that the benefits of using strategic planning techniques include increasing environmental awareness, risk reduction and priority establishment.

Hence we propose that:

Hypothesis H3: Planning tools have a significant influence on performance.

\subsection{Strategic Planning Systems and Firm Performance}

Strategic planning systems impact on firm performance through different channels. According to available studies, conceptualization of strategic planning systems considers both the contextual and design variables. In this study, conceptualization of strategic planning systems took cognizance of the work of many scholars; [5] [10] [13] [42]. A general conclusion that emerges from the above studies is that strategic planning systems are a combination of many subsystems. [13] posited that the organization ability to engineer the right configuration of strategic planning systems fosters strategic alignment and adaptability. In essence, well configured systems become more effective in the future. In line with [10] the appropriate configuration eventually leads to the achievement of superior performance.

Past studies have recognized the positive association between strategic planning systems and firm performance [5] [10] [13]. [42] in their study argued that changes in the level of participation leads to positive changes in effectiveness. They argued that participatory planning systems which are widely communicated improve effectiveness. They concluded that in participative environments the planning function becomes well integrated into the decision making process leading to better performance. On the other hand, [11] argued that planning effectiveness is measured by how well the strategic planning systems meet the intended goals like identification of new business opportunities which had been previously overlooked within the business environment.

A good configuration of strategic planning systems eventually fosters performance. Such a configuration encompasses enough resources provided for planning, participative management style and application of appropriate planning techniques. This is because the ultimate effectiveness of strategic choices are reflected in the ability of the system to yield positive business performance. Planning systems enables the organization to manage turbulent environment and achieve strategic alignment which sustains business growth. [43] recognized that strategies are formulated through resource capabilities which are redeployed. Planning systems define how the organization ultimately achieves the objectives through resources, participation and the subsequent use of planning techniques. Strategic planning systems affect the outcomes of strategies. If the resources are adequate, participation spread along different cadre and appropriate use of planning techniques are in use, organizations enhance chances of success.

One of the key planning systems is management participation in the strategy process. [44] observed that participation in strategic change has a number of 
positive consequences. He argued that managers need to participate in the planning process so as to formulate better plans and facilitate strategy implementation success. [31] argued that managerial participation increases the number of strategic alternatives hence diversifying strategic choices thus enabling choice of the best alternative.

We hypothesize that:

H4: Strategic planning systems as an aggregate factor has a greater influence on performance than its domains.

\section{Methodology}

This study adopted an analytical cross sectional design. Since the main drive was to the relationship between strategic planning systems and performance. The sampling frame which had 84 firms in EPZs in Kenya was obtained from Export Processing Zones Authority (EPZA). The determination of an appropriate sample size is important for a researcher to have a credible representation of the population. There are different methods available for sample size determination. This study adopted [45] procedure of sample size determination. The approach is based on population size and the basic minimum is 100 units. For this study, total operational firms were 84; we derived this figure after eliminating those that had closed shop although still on the register, others had been licensed but not yet operational and others we assessed as not structured adequately to fit into our conceptualization. We therefore based on the 84 operational firms to test our model. This was adequate since our analysis was based on within variables parameters but with the firm as our unit of analysis.

The population of this study comprised all operational EPZ firms in Kenya. The EPZ provided a rich context for this study because firms are distributed in different sectors, a factor which enhances representation in regard to different business areas. Further, the firms belong to a controlled environment which is defined by special incentives that give the firms fiscal, procedural and infrastructural advantages. Lastly, the EPZ firms by their very nature have a global orientation stemming from export business which enabled the study to achieve a global focus. Primary data was collected through structured questionnaires while secondary data was collected through document review. Respondents were members from the management teams of EPZ firms. Chief Executive Officers (CEO) and directors were preferred because they are the vision bearers within the firms. Strategic management literature reveals that top management decisions play a crucial role in defining the organizational position.

Reliability test was done through Cronbachs' Alpha coefficients. The coefficients range from 0 to 1 and the higher the coefficient, the more reliable the scale. The overall Alpha coefficient for the sample was put at recommended value of 0.70 [46] Content validity for this study was determined through pilot study. A pilot study was carried out before rolling out the main study. After the pilot study, the questionnaire was modified according to the data sets established in EPZs. Data analyzed for this study was collected from 40 firms making 62.5 
percent response rate. Strategic planning systems was operationalized in three components namely resources with interest on allocated space, networks, personnel and financial capability; management participation looked at influence, time and communication. The planning tools were operational standards, innovative processes and quality controls. For performance we considered both financial and non financial measures. All these are well supported in the literature.

\section{Results and Discussion}

Descriptive statistics supported a significant influence of resources on performance in EPZ firms we proceeded to test the hypothesis to confirm the results.

H1: Resources have a significant influence on performance

Testing $\mathrm{H} 1$ was done through regression of resource items against the composite variable of market performance and internal business process performance. The change statistics results are presented in Table 1 . The results showed resources led to a variation of $30.1 \%$ in EPZ firms. The remaining $69.9 \%$ was due to other factors not revealed in this model and accounted for by the error term. Therefore the model had a very strong fit. We then used the p-value to test the hypothesis. Significance level: 0.05\% (95\%). Decision Rule: Reject the $\mathrm{H}_{0}$ if the $\mathrm{p}$-value is less than 0.05 . P value is 0.016 , less than 0.05 .

Therefore we fail to reject the statistical hypothesis, $\mathrm{H} 1$ and conclude that there is evidence that resources significantly affect performance.

The results of the study were significant therefore support extant literature. [25] posited that firms which configure resources according to the dictates of the context achieve better performance. [10] emphasized the role of planning resources in the achievement of better performance. Resource based view scholars settled for a strong relationship between resources and firm performance [47]; [48]. Studies on organizational resources have a long history in strategic management in terms of determining competitive advantage. This basic concern has surfaced in the resource based view of the firm which has directed attention to important resource endowments of firms within industries [19] [47].

Having confirmed that there was evidence of resources were significant in performance we proceeded to examine the relationship between management participation and performance. $\mathrm{H} 2$ tested for this relationship using coefficient of determination and p-value. The results are found in Table 2.

H2: Management participation has a significant influence on performance

Testing $\mathrm{H} 2$ was done through regression of management participation items against composite variable of market performance and internal business process

Table 1. Resources and performance.

\begin{tabular}{ccccccc}
\hline \multicolumn{7}{c}{ Model Summary } \\
\hline Model & $\mathrm{R}$ & R Square & F Change & df1 & df2 & Sig. F Change \\
1 & 0.549 & 0.301 & 3.557 & 4 & 33 & 0.016 \\
\hline
\end{tabular}


performance. The change statistics results are presented in Table 2. The results showed management participation led to a variation of $33.7 \%$ in EPZ firms. The remaining $66.7 \%$ is accounted for by the error term. Therefore the model had a moderate fit. We then used the p-value to test the hypothesis. Significance level: $0.05 \%(95 \%)$. $p$ value is 0.007 , less than 0.05 . Therefore we fail to reject the statistical hypothesis, $\mathrm{H} 2$ and conclude that management participation significantly affect performance.

[32] argued that performance is influenced by what happens at middle level management. On the contrary, [44] and [5] reported no significant relationships between management participation and firm performance. This study reported significant relationship between management participation and none financial performance. These findings are in line with prior studies that focused on management participation. [42] study done in UK established a direct relationship between management participation and effectiveness.

\section{H3: Planning tools have a significant influence on performance}

Testing $\mathrm{H} 3$ was done through regression of planning tools items against composite variable of market performance and internal business process performance. The change statistics results are presented in Table 3 . The results showed resources led to a variation of $26.5 \%$ in EPZ firms. The remaining $74.5 \%$ was due to other factors not revealed in this model. Therefore the model had a very strong fit. We then used the p-value to test the hypothesis. Significance level: $0.05 \%$ (95\%). $\mathrm{p}$ value is 0.043 , less than 0.05 . Therefore we fail to reject the statistical hypothesis, $\mathrm{H} 3$ and conclude that management participation significantly affect performance.

This study established significant relationships with non financial performance measures. [13] in a study focusing on fortune 500 manufacturing and service companies established that, planning techniques do influence organizational effectiveness. [5] established that planning practice which was defined in terms of use of planning techniques was significantly associated with effectiveness. A consensus arising from the studies is that planning techniques benefit organizations by enabling them to discern changes and establish market trends. [38] investigated Saudi Arabian organizations and highlighted the importance of planning techniques. He posited that the most commonly and widely used techniques were analysis of critical success factors, followed by benchmarking.

Table 2. Management participation and performance.

\begin{tabular}{ccccccc}
\hline \multicolumn{7}{c}{ Model Summary } \\
\hline Model & R & R Square & F Change & df1 & df2 & Sig. F Change \\
1 & 0.581 & 0.337 & 4.199 & 4 & 33 & 0.007 \\
\hline
\end{tabular}

Table 3. Planning tools and performance.

\begin{tabular}{ccccccc}
\hline \multicolumn{7}{c}{ Model Summary } \\
\hline Model & R & R Square & F Change & df1 & df2 & Sig. F Change \\
1 & 0.515 & 0.265 & 2.792 & 4 & 31 & 0.043 \\
\hline
\end{tabular}


Having tested all the individual planning systems and established a positive significant influence of each, we proceeded to test the influence of the aggregate factor namely strategic planning systems on performance.

H4: Strategic planning systems as an aggregate factor has a greater influence on performance than its domains.

Testing $\mathrm{H} 4$ was done through regressing the composite variable of strategic planning systems against aggregate performance. The change statistics results are presented in Table 4. The results showed a coefficient of determination of 0.447 which means that the factor accounts for $47.4 \%$ variation in the performance of EPZ firms. The remaining 52.6\% was due to other factors not revealed in this model. At a significance level of $95 \%$ (0.05), the p-value was 0.000 which was less than 0.05 . We thus failed to reject $\mathrm{H} 4$ and conclude that there was evidence that strategic planning systems as an aggregate variable accounts for performance with a higher coefficient that its domains.

Planning systems must be viewed as a configuration. The domains provide a less influence on their own but will determine performance more when they are considered together as a system. These results are in partial agreement with past findings. [13] study indicated that organizational context of planning had dominant impact on planning system effectiveness. In this case we need to view the system in its entirelity. Accordingly the context comprised of the tools and techniques of planning. [5] established that both strategic planning practice and management participation jointly enhanced the effectiveness of strategic planning in Egyptian firms. The results of the study indicated the overriding importance of considering the influence of strategic planning systems on performance rather than considering isolated variables. This study established significant relationship between strategic planning systems and internal business processes on the one side and market performance on the other. In theoretical perspective, the planning systems were resource bundles which firms acquire for growth. [4] posited that a firm's planning systems need to achieve a balance between adaptation and integration.

\section{Implications and Contributions}

This study makes a contribution to strategic management literature by proving results from a developing country context on strategic planning systems, a hitherto widely explored concept in industrialized countries. We established that strategic planning systems are valuable resource bundles in confirmation of previous studies. From the study, financial resources, business contacts and networks, economies of scale and product differentiation were singled out as scarce,

Table 4. Planning systems and performance.

\begin{tabular}{ccccccc}
\hline \multicolumn{7}{c}{ Model Summary } \\
\hline Model & R & R Square & F Change & df1 & df2 & Sig. F Change \\
1 & 0.688 & 0.474 & 9.596 & 3 & 32 & 0.000 \\
\hline
\end{tabular}


rare, inimitable and valuable resources that facilitated competitive advantage in EPZ firms in the Kenyan setting. It is thus a contribution to current knowledge on the resource based view of the firm. Another theoretical underpinning is the dynamic capability theory. We note that in the EPZ firms, transformation of firm resources is achieved through dynamic capabilities inherent in learning, integration and configuration. The results of this study shows evidence of equifinality as posited by the open systems theory. Through the moderation role of strategy implementation, this study demonstrates that sustained performance is a function of successful embedded management processes.

This study contributes to business and public policy by providing evidence of the correlation between planning systems and the performance. The EPZs have become instruments of economic policy development in developing countries seeking to gain advantages from the growing integration of the global economy. In essence, policy makers need to consider the alignment of policy recommendations and important firm attributes to enhance the achievement of better performance. In Kenya, the policy makers will utilize the findings of the study to advice firms operating within EPZs on appropriate configuration of planning systems to facilitate better performance.

\section{Conclusion}

Despite the plethora of writings on strategic issues, managers still appear unaware of the use of specific frameworks in strategic planning. The findings of this study raise two conclusions which have practical implications. The study supports the fact that strategic planning techniques are important to the achievement of performance. Managers within an organization matter in determining firm success. An effective planning system requires an infusion of adequate resources to the planning efforts as well as knowledge of relevant planning techniques. The research findings indicate that participatory management approaches are important as they enhance strategy implementation success and performance.

\section{Limitations}

The results of this study should be interpreted in light of some methodological limitations. The mix of our firm respondents and the industry heterogeneity could have affected our chosen measures. The firms were in different sectors although within the EPZ. This could have been affected the environmental context in which data was collected and the interpretation of the results. The operationalization of the variables may also not have been homogenously understood by the various respondents. We also lacked local literature to underpin the constructs. We however, contend that overall, the results make a significant contribution to current knowledge in strategic management.

\section{References}

[1] Armstrong, J.S. (1982) The Value of Strategic Planning for Strategic Decisions: Re- 
view of Empirical Research. Strategic Management Journal, 3, 197-211. https://doi.org/10.1002/smj.4250030303

[2] Miller, C.C. and Cardinal, L.B. (1994) Strategic Planning and Firm Performance: A Synthesis of more than Two Decades of Research. Academy of Management Journal, 37, 1649-1665. https://doi.org/10.2307/256804

[3] Mankins, M. and Steele, R. (2005) Turning Great Strategy into Great Performance. Harvard Business Review, 83, 65-72.

[4] Jennings, D. and Disney, J. (2006) The Strategic Planning Process and Its Context: The Role of Psychological Type. Journal of General Management, 31, 75-93. https://doi.org/10.1177/030630700603100305

[5] Elbanna, S. (2008) Planning and Participation as Determinants of Strategic Planning Effectiveness: Evidence from Arabic Context. Management Decision, 46, 779796. https://doi.org/10.1108/00251740810873761

[6] Falshaw, J.R., Glaister, K.W. and Tatoglu, E. (2006) Evidence on Formal Strategic Planning and Company Performance. Management Decision, 44, 9-30. https://doi.org/10.1108/00251740610641436

[7] Johansson, H. and Nilsson, L. (1997) Export Processing Zones as Catalysts. World Development, 25, 2115-2128. https://doi.org/10.1016/S0305-750X(97)00103-4

[8] EPZA (2008) Export Processing Zones Score Card. Annual Report.

[9] Shah, K.U. and Rivera, J.E. (2007) Export Processing Zones and Corporate Environmental Performance in Emerging Economies. Policy Sciences, 40, 265-285. https://doi.org/10.1007/s11077-007-9045-8

[10] Ramanujam, V., Venkatraman, N. and Camilus, J. (1986) Multi-Objective Assessment of Effectiveness of Strategic Planning: A Discriminant Analysis Approach. Academy of Management Journal, 29, 347-372. https://doi.org/10.2307/256192

[11] King, R.K. (1983) Evaluating Strategic Planning Systems. Strategic Management Journal, 4, 263-277. https://doi.org/10.1002/smj.4250040307

[12] Glaister, K.W. and Falshaw, J.R. (1999) Strategic Planning: Still Going Strong? Long Range Planning, 32, 107-116. https://doi.org/10.1016/S0024-6301(98)00131-9

[13] Ramanujam, V. and Venkatraman, N. (1987) Planning Systems Characteristics and Planning Effectiveness. Strategic Management Journal, 8, 453-468. https://doi.org/10.1002/smj.4250080505

[14] O’Regan, N., Sims, M.A. and Gallear, D. (2008) Leaders, Loungers, Laggard: The Strategic Planning, Environment, Performance Relationship Re-Visited in Manufacturing Small and Medium Enterprises. Journal of Manufacturing Technology Management, 19, 6-21. https://doi.org/10.1108/17410380810843426

[15] Chakravarthy, B.S. (1986) Measuring Strategic Performance. Strategic Management Journal, 7, 437-458. https://doi.org/10.1002/smj.4250070505

[16] Srimai, S., Damsaman, N. and Bangchokdee, S. (2011) Performance Measurement, Organizational Learning and Strategic Alignment. Measuring Business Excellence, 15, 57-69. https://doi.org/10.1108/13683041111131628

[17] Kaplan S.R. (2001) Strategic Performance Measurement and Management in NonProfit Organizations. Nonprofit Management and Leadership, 11, 353-370. https://doi.org/10.1002/nml.11308

[18] Grant, R.M. (2003) Strategic Planning in a Turbulent Environment: Evidence from the Oil Majors. Strategic Management Journal, 24, 491-517. https://doi.org/10.1002/smj.314

[19] Wernerfelt, B. (1984) The Resource-Based View of the Firm. Strategic Management 
Journal, 5, 171-180. https://doi.org/10.1002/smj.4250050207

[20] Teece, D.J., Pisano, G. and Shuen, A. (1990) Firm Capabilities, Resources and the Concept of Strategy. Economic Analysis and Policy Working Paper EAP, 38, University of California, Oakland, CA.

[21] Girod, S.J.G. and Whittington, R. (2015) Change Escalation Processes and Complex Adaptive System. From Incremental Reconfigurations to Discontinuous Restructuring. Organizational Science, 26, 1520-1535. https://doi.org/10.1287/orsc.2015.0993

[22] Teece, D.J., Pisano, G. and Shuen, A. (1997) Dynamic Capabilities and Strategic Management. Strategic Management Journal, 18, 509-533. https://doi.org/10.1002/(SICI)1097-0266(199708)18:7<509::AID-SMJ882>3.0.CO;2-Z

[23] Penrose, E. (1959) The Theory of the Growth of the Firm. Basic Blackwell, Oxford.

[24] Ambrosini, V. and Bawman, C. (2009) What Are Dynamic Capabilities and Are They a Useful Construct in Strategic Management? International Journal of Management Reviews, 11, 29-49. https://doi.org/10.1111/j.1468-2370.2008.00251.x

[25] Helfat, C.E. and Petaraf, M.A. (2003) The Dynamic Resource Based View: Capability Life Cycles. Strategic Management Journal, 24, 997-1010. https://doi.org/10.1002/smj.332

[26] Porter, M.E. (1980) Competitive Strategy: Techniques for Analyzing Industries and Competitors. Free Press, New York.

[27] Connor, T. (2002) The Resource Based View of Strategy and its Value in Practicing Managers. Strategic Change, 11, 307-316. https://doi.org/10.1002/jsc.593

[28] McGuiness, T. and Morgan, R.E. (2000) Strategy, Dynamic Capabilities and Complex Science: Management Rhetoric vs Reality. Strategic Change, 9, 209-220. https://doi.org/10.1002/1099-1697(200006/07)9:4<209::AID-JSC485>3.0.CO;2-G

[29] Ketokivi, M. and Gastner, X. (2004) Strategic Planning as an Integrative Device. Administrative Science Quarterly, 49, 337-365.

[30] Ogbeide, G.A. and Harrington, J.R. (2011) The Relationship among Participative Management Styles, Strategy Implementation and Performance in Service Industry. International Journal of Hospitality Management, 23, 719-738.

[31] Feigner, M.K. (2005) Determinants of Board Participation in the Strategic Decisions of Small Corporations. Entrepreneurship Theory and Practice, 29, 627-650. https://doi.org/10.1111/j.1540-6520.2005.00101.x

[32] Currie, G. and Procter, S.J. (2005) The Antecedents of Middle Managers Strategic Contribution: The Case of Professional Bureaucracy. Journal of Management Studies, 42, 1325-1355. https://doi.org/10.1111/j.1467-6486.2005.00546.x

[33] Floyd, S.W. and Wooldridge, B. (1990) Middle Management Involvement in Strategy and Its Association with Strategic Type. Strategic Management Journal, 13, 153 167. https://doi.org/10.1002/smj.4250131012

[34] Floyd, S.W. and Wooldridge, B. (1997) Middle Management's Strategic Influence and Organizational Performance. Journal of Management Studies, 34, 465-485. https://doi.org/10.1111/1467-6486.00059

[35] Tegarden, L.F., Sarason, Y. and Banbury, C. (2003) Linking Strategy Process to Performance Outcomes in Dynamic Environments: The Need to Target Multiple Bull's Eyes. Journal of Managerial Issues, 9, 133-153.

[36] Andersen, T.J. (2000) Strategic Planning, Autonomous Actions and Corporate Performance. Long Range Planning, 33, 184-200. https://doi.org/10.1016/S0024-6301(00)00028-5

[37] Stonehouse, G. and Pembertone, J. (2002) Strategic Planning in Small and Medium 
Enterprises. Management Decision, 40, 853-861.

https://doi.org/10.1108/00251740210441072

[38] Ghamdi, S.M. (2005) Use of Strategic Planning Tools and Techniques in Saudi Arabia: An Empirical Study. International Journal of Management, 22, 376-395.

[39] Amran, M. and Kulatilaka, N. (1999) Uncertainty, the New Rules of Strategy. Journal of Business Strategy, 20, 25-29. https://doi.org/10.1108/eb040003

[40] Aldehayyat, J.S. and Khattab, A.A. (2011) The Use of Strategic Planning Tools and Techniques by Hotels in Jordan. Management Research Review, 34, 477-490. https://doi.org/10.1108/01409171111117898

[41] Dincer, O., Tatoglu, E. and Glaister, K.W. (2006) The Strategic Planning Process: Evidence from Turkish Firms. Management Research News, 29, 206-219. https://doi.org/10.1108/1409170610665068

[42] Dayson, R.G. and Foster, M.J. (1982) The Relationship of Participation and Effectiveness in Strategic Planning. Strategic Management Journal, 3, 77-88. https://doi.org/10.1002/smj.4250030107

[43] Eggers, J.P. and Kaplan, S. (2013) Cognition and Capabilities: A Multi-Level Perspective. Academy of Management Annals, 7, 295-340. https://doi.org/10.1080/19416520.2013.769318

[44] Lines, R. (2004) Influence of Participation in Strategic Change: Resistance, Organizational Commitment and Change Goal Achievement. Journal of Change Management, 4, 193-215. https://doi.org/10.1080/1469701042000221696

[45] Bartlett, J.E. Kotrlik, J.W. and Higgins, C. (2001) Organizational Research: Determining Appropriate Sample Size in Survey Research. Information Technology, Learning and Performance Journal, 19, 43-50.

[46] Holcomb, T.R., Holmes, R.M. and Connelly, B.L. (2009) Making the Most of What You Have: Managerial Ability as Source of Resource Value Creation. Strategic Management Journal, 30, 457-485. https://doi.org/10.1002/smj.747

[47] Barney, J.B. (2001) Resource-Based Theories of Competitive Advantage: A Ten Year Retrospective on the Resource-Based View. Journal of Management, 27, 643-650. https://doi.org/10.1177/014920630102700602

[48] Newbert, S.L. (2007) Empirical Research on Resource Based View of the Firm: An Assessment and Suggestions for Future Research. Strategic Management Journal, 28, 121-146. https://doi.org/10.1002/smj.573

\section{Submit or recommend next manuscript to SCIRP and we will provide best service for you:}

Accepting pre-submission inquiries through Email, Facebook, LinkedIn, Twitter, etc. A wide selection of journals (inclusive of 9 subjects, more than 200 journals) Providing 24-hour high-quality service User-friendly online submission system Fair and swift peer-review system Efficient typesetting and proofreading procedure Display of the result of downloads and visits, as well as the number of cited articles Maximum dissemination of your research work

Submit your manuscript at: http://papersubmission.scirp.org/

Or contact ajibm@scirp.org 